\title{
Correction to: The Effect of Aging on the Microstructure of Selective Laser Melted Cu-Ni-Si
}

\author{
ANTHONY P. VENTURA, CHRISTOPHER J. MARVEL, GREGORY PAWLIKOWSKI, \\ MARTIN BAYES, MASASHI WATANABE, RICHARD P. VINCI, \\ and WOJCIECH Z. MISIOLEK
}

https://doi.org/10.1007/s11661-017-4395-0

(C) The Minerals, Metals \& Materials Society and ASM International 2017

\begin{abstract}
Correction to: Metallurgical and Materials Transactions A https://doi.org/10.1007/s11661-017-4363-8
\end{abstract}

IN the Experimental Methods section, second paragraph, last sentence of the original article the value for the resistivity of pure copper is incorrect. The correct value is $1.7241 \mu \Omega-\mathrm{cm}$.

ANTHONY P. VENTURA is with the Materials Science and Engineering Department, Loewy Institute, Lehigh University, Bethlehem, PA 18015 and also with Pratt \& Whitney, Materials \& Processes Engineering, East Hartford, CT 06118. Contact e-mail: AnthonyPVentura@gmail.com CHRISTOPHER J. MARVEL, MASASHI WATANABE, and RICHARD P. VINCI are with the Materials Science and Engineering Department, Lehigh University, Bethlehem, PA 18015. GREGORY PAWLIKOWSKI and MARTIN

BAYES are with Tyco Electronics Corporation, a TE Connectivity Company, Harrisburg, PA 17111. WOJCIECH Z. MISIOLEK is with the Materials Science and Engineering Department, Loewy Institute, Lehigh University.

The original article can be found online at https://doi.org/10.1007/ s11661-017-4363-8.

Article published online November 13, 2017 